Acta vet. scand. 1971, 12, 202--219.

From the Department of Special Pathology and Therapeutics,

Royal Veterinary and Agricultural University, Copenhagen, and the National Institute of Animal Science, Copenhagen, Denmark.

\title{
DIETARY CALCIUM-PHOSPHORUS RATIOS FOR GROWING PIGS IN RELATION TO SERUM LEVELS AND BONE DEVELOPMENT
}

\author{
By
}

N. C. Nielsen $\left.{ }^{\star}\right)$, S. Andersen, A. Madsen and H. P. Mortensen

Degenerative arthritis seems to play an increasing role among the joint lesions developing in growing pigs and young breeding animals (i. a. Christensen 1953; Schilling 1958; Sabec et al. 1961; Eikmeier \& Mayer 1965; Thurley 1965; Lauprecht et al. 1967; Nordrum 1968). One main type of pathologic findings is a change in the articular cartilage which takes on a dry, dull yellowish, granular appearance with small clefts and fissures followed by splitting and fibrillation ending up with erosions and exposed subchondral bone. The other main type of pathologic findings is an invagination of articular cartilage with fibrous replacement of underlying bone and deformation of the articular surface (Nielsen 1965). At least the last type of changes gives the impression that disturbance in bone development and bone strength could be involved in the pathogenesis. Another condition which involves - at least local - disturbance in bone tissues is atrophic rhinitis. Recently Brown et al. (1966) found that nutritional $\mathrm{Ca}$ and $\mathrm{P}$ supplement was playing an etiological role in the 2 conditions mentioned.

As a contribution to the discussions of the diagnostic value of biochemical determination of serum $\mathrm{Ca}$, inorg. $\mathrm{P}$, and alkaline phosphatase in nutritional bone disorders and to $\mathrm{Ca}$ and $\mathrm{P}$ requirements in growing pigs in relation to the development of

*) The author was holding a grant from Statens teknisk-videnskabelige Fond during part of the work. 
degenerative arthritis and atrophic rhinitis, 2 experiments (sv. 474 and sv. 514), each comprising 40 pigs divided into 4 groups fed different levels of $\mathrm{Ca}$ and $\mathrm{P}$, were carried out.

\section{MA'TERIAL ANI) METHODS}

For each experiment 10 litters of 4 castrated male pigs of Danish Landrace were purchased at about 7 weeks of age. The 4 animals from each litter were divided at random into 4 experimental groups. During the pre-experimental period all pigs were fed a ration composed of barley and protein concentrates. From $20 \mathrm{~kg}$ up to slaughter at $90 \mathrm{~kg}$ live-weight the pigs were kept individually in pens with concrete floor and straw as bedding. Feed was weighed out and recorded daily, and body weight was recorded weekly.

The pigs were fed a restricted diet twice a day, the only difference being the amount of $\mathrm{Ca}$ and $\mathrm{P}$ as shown in Table 1. All mixtures were supplemented with 600 i. u. vitamin $D_{3}$ and 80 p.p.m. Zn per kg.

T a ble 1. Composition of the experimental diets.

\begin{tabular}{|c|c|c|c|c|}
\hline Diet for group no. & 1 & 2 & 3 & 4 \\
\hline \multicolumn{5}{|c|}{ Experiment sv. 仵 } \\
\hline Extr. soybean meal, \% & 18.0 & 18.0 & 18.0 & 18.0 \\
\hline Barley, \% & 80.5 & 79.5 & 78.5 & 77.5 \\
\hline Sodium chloride, \% & 0.4 & 0.4 & 0.4 & 0.4 \\
\hline Vitamins + trace elements, $\%$ & 0.1 & 0.1 & 0.1 & 0.1 \\
\hline Calcium carbonate, $\%$ & 1.0 & 0.8 & 0.7 & 0.6 \\
\hline Dicalicum phosphate, \% & - & 1.2 & 2.3 & 3.4 \\
\hline $\mathrm{Ca}$, g per kg mixture & 4.8 & 7.2 & 9.6 & 12.0 \\
\hline $\mathrm{P}, \mathrm{g}$ per kg mixture & 4.0 & 6.0 & 8.0 & 10.0 \\
\hline $\mathrm{Ca}: \mathrm{P}$ & 1.2 & 1.2 & 1.2 & 1.2 \\
\hline \multicolumn{5}{|c|}{ Experiment sv. 514} \\
\hline Extr. soybean meal, \% & 18.0 & 18.0 & 18.0 & 18.0 \\
\hline Barley, \% & 79.5 & 81.5 & 78.4 & 78.7 \\
\hline Sodium chloride, $\%$ & 0.4 & 0.4 & 0.4 & 0.4 \\
\hline Vitamins + trace elements, $\%$ & 0.1 & 0.1 & 0.1 & 0.1 \\
\hline Calcium carbonate, $\%$ & 0.8 & - & - & 2.8 \\
\hline Dicalcium phosphate, \% & 1.2 & - & - & - \\
\hline Mono sodium phosphate, \% & - & - & 3.1 & - \\
\hline $\mathrm{Ca}$, g per $\mathrm{kg}$ mixture & 7.2 & 0.9 & 0.9 & 12.0 \\
\hline $\mathrm{P}$, g per kg mixture & 6.0 & 4.0 & 10.0 & 4.0 \\
\hline $\mathrm{Ca}: \mathrm{P}$ & 1.2 & 0.2 & 0.1 & 3.0 \\
\hline
\end{tabular}


The pigs were examined clinically every week. At slaughter carcass data were collected, the scapulas were removed for ash determination and determination of $\mathrm{Ca}$ and $\mathrm{P}$ in the ash. The noses were sliced through the canine teeth and examined macroscopically for atrophic rhinitis according to Bendixen (1957). Tissue specimens for histological examination were taken from the turbinates, a rib, and a non-weight bearing epiphyseal line in digits II and V (metatarsal-phalangeal joint). The tissues were fixed in formalin, demineralized in formic acid - sodium formiate solution, embedded in paraffin, and stained with hematoxylin-eosin and additional other stains.

In experiment sv. 514 the following additional examinations were performed: Radiological examination of the noses at the beginning of the experiment and after 11 weeks, weekly determination of serum $\mathrm{Ca}$, inorg. $\mathrm{P}$, and alkaline phosphatase during the first 11 weeks of the experiment and then every second week throughout the experiment; p. m. examination was undertaken of all the joint surfaces of a front and a hind leg from each pig. Serum Ca was determined by Atomic Absorption Spectrophotometry (Perkin-Elmer 1964); serum inorg. P was determined according to Shinowara et al. (1942) (mod.), and serum alkaline phosphatase according to Bessey et al. (1946)*).

\section{Sv. 474}

\section{RESULTS}

Data from experiment sv. 474 are shown in 'Table 2. All the pigs grew well except for 1 in group 1, it lost appetite for some time due to pneumonia. The pig recovered and was slaughtered at $90 \mathrm{~kg}$, but was discarded from the experiment. No significant differences were observed in average daily gain and feed conversion.

Clinically no lameness or locomotor disturbances were observed. One pig in group 1 and 1 in group 3 developed clinical symptoms of atrophic rhinitis.

The carcass measurements did not show any linear effect of $\mathrm{Ca}$ and $\mathrm{P}$ levels. With increasing amounts of $\mathrm{Ca}$ and $\mathrm{P}$ in the

*) The authors are indebted to M. G. Simesen, D.V.M. for aid in the estimation of serum $\mathrm{Ca}$ and inorg. $\mathrm{P}$. The determination of serum alkaline phosphatase was kindly carried out by the State Veterinary Serum Laboratory, Copenhagen. 
Table 2. Performance of pigs fed different levels of Ca and P. $\mathrm{Ca}: \mathrm{P}$ ratio $=1.2$.

\begin{tabular}{lcccc}
\hline $\begin{array}{l}\text { Experiment sv. 474, } \\
\text { dietary group }\end{array}$ & 1 & 2 & 3 & 4 \\
\hline Ca, \% & 0.48 & 0.72 & 0.96 & 1.20 \\
P, \% & 0.40 & 0.60 & 0.80 & 1.00 \\
No. of pigs per treatment & 10 & 10 & 10 & 10 \\
Daily gain, g & 662 & 660 & 671 & 665 \\
F. u. per kg gain & 2.81 & 2.83 & 2.80 & 2.83 \\
Weight of scapula, g & 106 & 112 & 120 & 116 \\
Ash,\% of fat free dry matter & 58.6 & 60.1 & 60.6 & 61.1 \\
Ca, \% in ash & 37.4 & 36.1 & 37.6 & 37.0 \\
P,\% in ash & 17.2 & 16.8 & 17.5 & 17.5 \\
Ca:P ratio in ash & 2.16 & 2.14 & 2.15 & 2.12 \\
\hline
\end{tabular}

feed there was a tendency of increasing weight of scapula and increasing ash content in defatted dry matter. The percentage of $\mathrm{Ca}$ and $\mathrm{P}$ in the ash was, however, fairly constant, and so was the Ca: $\mathrm{P}$ ratio in the ash.

Besides the 2 clinical cases several pigs showed slight degrees of atrophic rhinitis at the cross sections of the noses. The distribution of cases of atrophic rhinitis is shown in Table 3. From this table it will be seen that no relation between dietary Ca and $P$ levels and atrophic rhinitis was found.

$\mathrm{T}$ a b le 3 . Incidence of atrophic rhinitis.

\begin{tabular}{lllll}
\hline $\begin{array}{l}\text { Experiment sv. 474, } \\
\text { dietary group }\end{array}$ & 1 & 2 & 3 & 4 \\
\hline $\begin{array}{c}\text { Degree of lesion *) } \\
0\end{array}$ & 1 & 2 & 3 & 2 \\
$?$ & 6 & 7 & 5 & 6 \\
+ & 2 & 1 & 0 & 2 \\
++ & 0 & 0 & 1 & 0 \\
+++ & 1 & 0 & 1 & 0 \\
\hline
\end{tabular}

*) $0=$ no pathological change. ? $-++=$ slight to very severe atrophy of conchae.

Histologically, various degrees of bone resorption were observed in groups 1,2 , and 3 (Figs. 1-4), most pronounced in group 1 , but also in several of the pigs in groups 2 and 3 the trabeculae in the turbinates were tiny with confluence of adjacent tubules filled with fibrous tissue. The bone surface appeared 


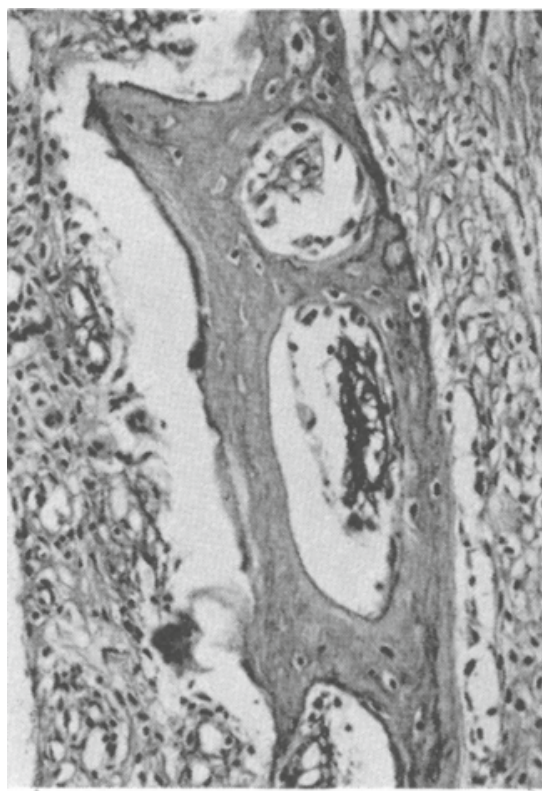

Fig u r e 1. Turbinate from pig no. 781, group 1, sv. 474. H. E. $\times 160$.

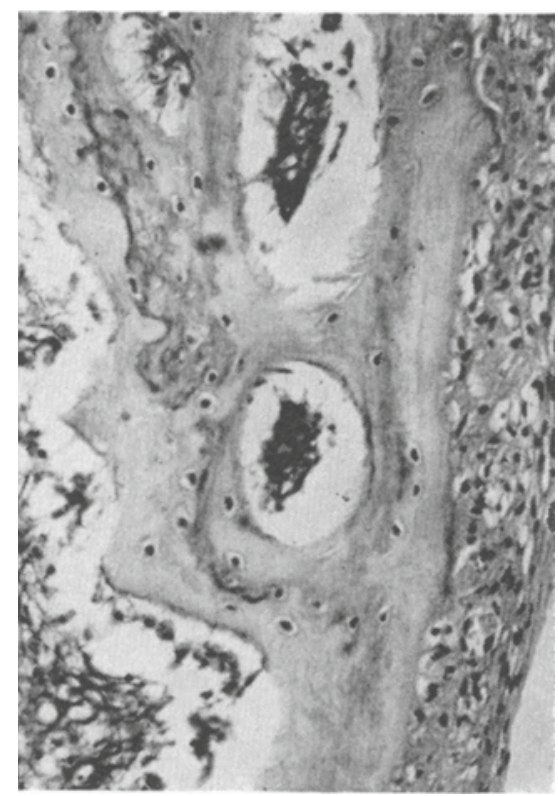

Fi g u r e 2. Turbinate from pig no. 783, group 2, sv. 474.

H. E. $\times 160$.

lacerated with reduced osteoblast activity. In many areas the mineralization seemed poor. Increased pericytic osteolysis was found in most of the pigs. Only a few osteoclasts were seen.

In the cortical bone of digits 2 and 5 the Haversian and Volkmann's canals were found wide and contained varying numbers of fibrils. The outer circumferential lamellae were often poorly developed. In group 4 the bone core in the turbinates was wide and consisted of strong, lamellated bone which seemed well mineralized. A normal layer of osteoblasts was lining bone surfaces (Fig. 4).

\section{Sv. 514}

In experiment sv. 514 the appetite was not affected. Some of the pigs, especially in group 3 developed diarrhea periodically during the experiment. No signs of parakeratosis were observed. One pig in group 1 died suddenly of a heart failure, and 1 pig in group 3 got a fracture of the left femur at a live-weight of $70 \mathrm{~kg}$. Clinically several of the pigs developed leg deformations

- most pronounced in group 4 . Some pigs became bow-legged, 


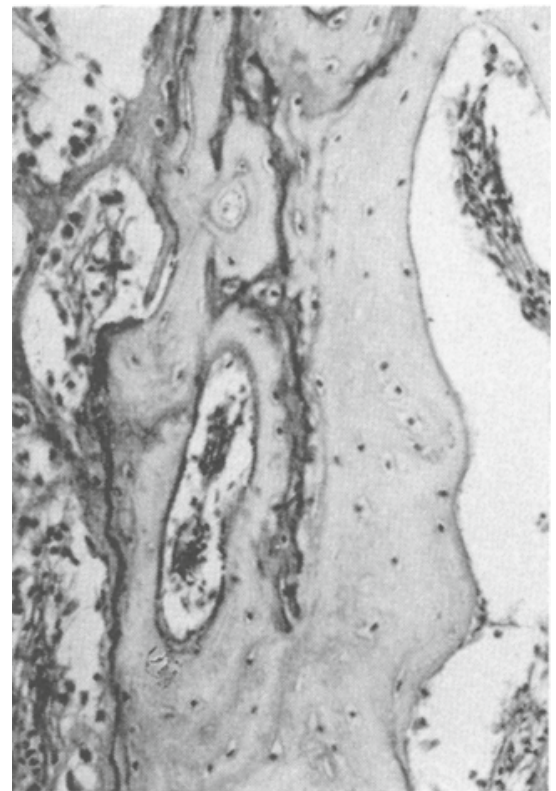

Figure 3. Turbinate from pig no. 784, group 3, sv. 474 . H. E. $\times 160$.

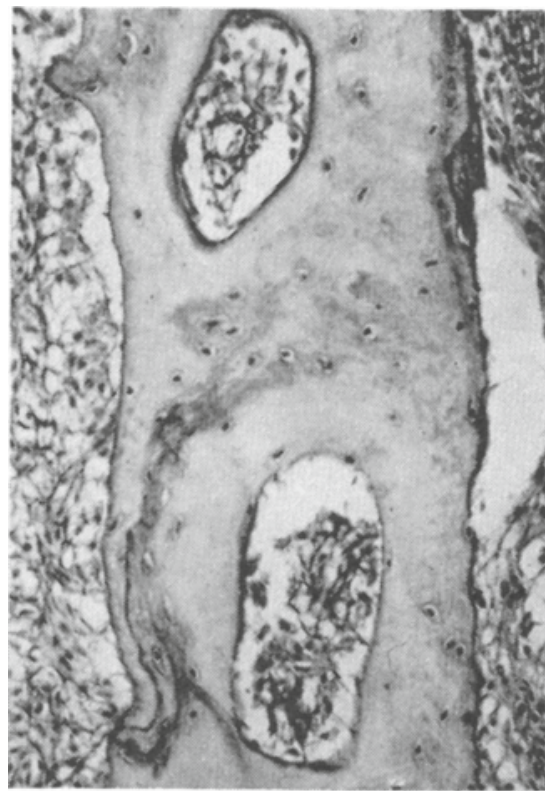

Figure 4. Turbinate from pig no. 782, group 4, sv. 474 . H. E. $\times 160$.

others cow-hocked with a tendency to knuckling over and walking with turned-in toes. Sore, toddling gait, trembling or convulsion were not observed. Only 2 pigs - from groups 1 and 4 respectively - showed atrophic rhinitis at radiological and clinical examination.

From Table 4 it will be seen that the groups 2, 3, and 4 had slightly lower weight gain and feed conversion than group 1 . The pigs on the recommended level of $\mathrm{Ca}$ and $\mathrm{P}$ (diet 1) contained more meat and less fat than the pigs on diets $2-4$. Weight and ash content of scapula were significantly higher in groups 1 and 4 than in groups 2 and 3 . The Ca:P ratio of ash varied from 2.07 to 2.20 , but the difference was not significant.

At the weekly determination of serum Ca a transient decrease was observed after 3 weeks in groups 2 and 3 , and another decrease was observed after about 11 weeks, but no significant hypocalcemia was found (see Fig. 5). In group 4 (high $\mathrm{Ca}$, low P) a significant rise in serum Ca occurred in less than 1 week, and with fluctuations - serum Ca stayed on a high level throughout the experiment. 
T a b l e 4. Performance of pigs fed various Ca: $\mathrm{P}$ ratios.

\begin{tabular}{lcccc}
\hline $\begin{array}{l}\text { Experiment sv. 514, } \\
\text { dietary group }\end{array}$ & 1 & 2 & 3 & 4 \\
\hline Ca, \% & 0.72 & 0.09 & 0.09 & 1.20 \\
P, \% & 0.60 & 0.40 & 1.00 & 0.40 \\
No. of pigs per treatment & 10 & 10 & 10 & 10 \\
Daily gain, g & 644 & 618 & 583 & 582 \\
F. u. per kg gain & 2.84 & 2.99 & 3.18 & 3.07 \\
Weight of scapula, g & 128 & 101 & 103 & 116 \\
Ash, \% of fat free dry matter & 56.6 & 53.2 & 52.3 & 56.4 \\
Ca,\% in ash & 36.2 & 35.7 & 36.7 & 36.5 \\
P,\% in ash & 17.0 & 17.3 & 17.4 & 16.5 \\
Ca:P ratio in ash & 2.13 & 2.06 & 2.11 & 2.21 \\
\hline
\end{tabular}

At the initial stage the inorg. $P$ content in serum decreased considerably whereafter it fluctuated (Fig. 6). However, a reverse relationship to the Ca content is seen with an increase after 3 weeks in groups 2 and 3 and another increase after about 10 weeks. For group 4 the level was relatively low throughout the experiment.

The serum alkaline phosphatase was very constant in groups 1, 2, and 3 (see Fig. 7). Only in group 4 a slight increase was noticed.

From Table 5 it will be seen that no differences in frequency of atrophic rhinitis were noticed among groups.

T a b l e 5. Incidence of atrophic rhinitis.

\begin{tabular}{lllll}
\hline $\begin{array}{l}\text { Experiment sv. 514, } \\
\text { dietary group }\end{array}$ & 1 & 2 & 3 & 4 \\
\hline $\begin{array}{c}\text { Degree of lesion (see Table 3) } \\
0\end{array}$ & 2 & 5 & 5 & 5 \\
$?$ & 5 & 5 & 4 & 4 \\
+ & 1 & 0 & 1 & 1 \\
++ & 1 & 0 & 0 & 0 \\
+++ & 0 & 0 & 0 & 0 \\
\hline
\end{tabular}

Degenerative joint lesions varied considerably among litters. Lesions were less pronounced in group 4 which confirms an observation made in a previous experiment (Madsen et al. 1966) viz. that the clinical symptoms of leg weakness and the lesions 


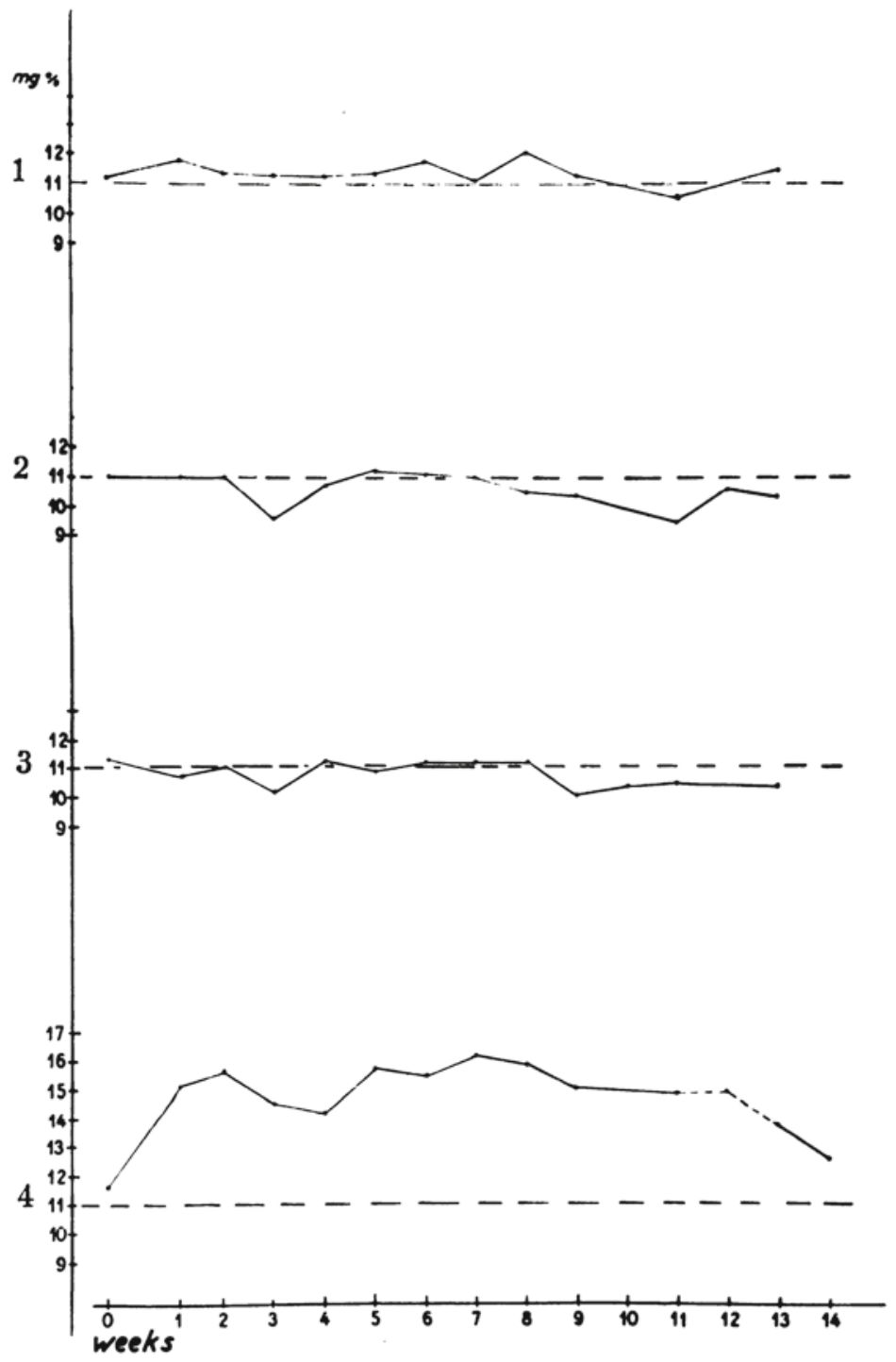

Fi g u r e 5. Serum Ca. Mean values of groups, sv. 514.

actually found on the joint surfaces are not necessarily correlated.

Invaginations on the unloaded cartilagenous joint surfaces with collaps of the supporting bone structure (Fig. 13) were found unrelated to the feeding scheme. Detailed description of the joint will be given elsewhere. 


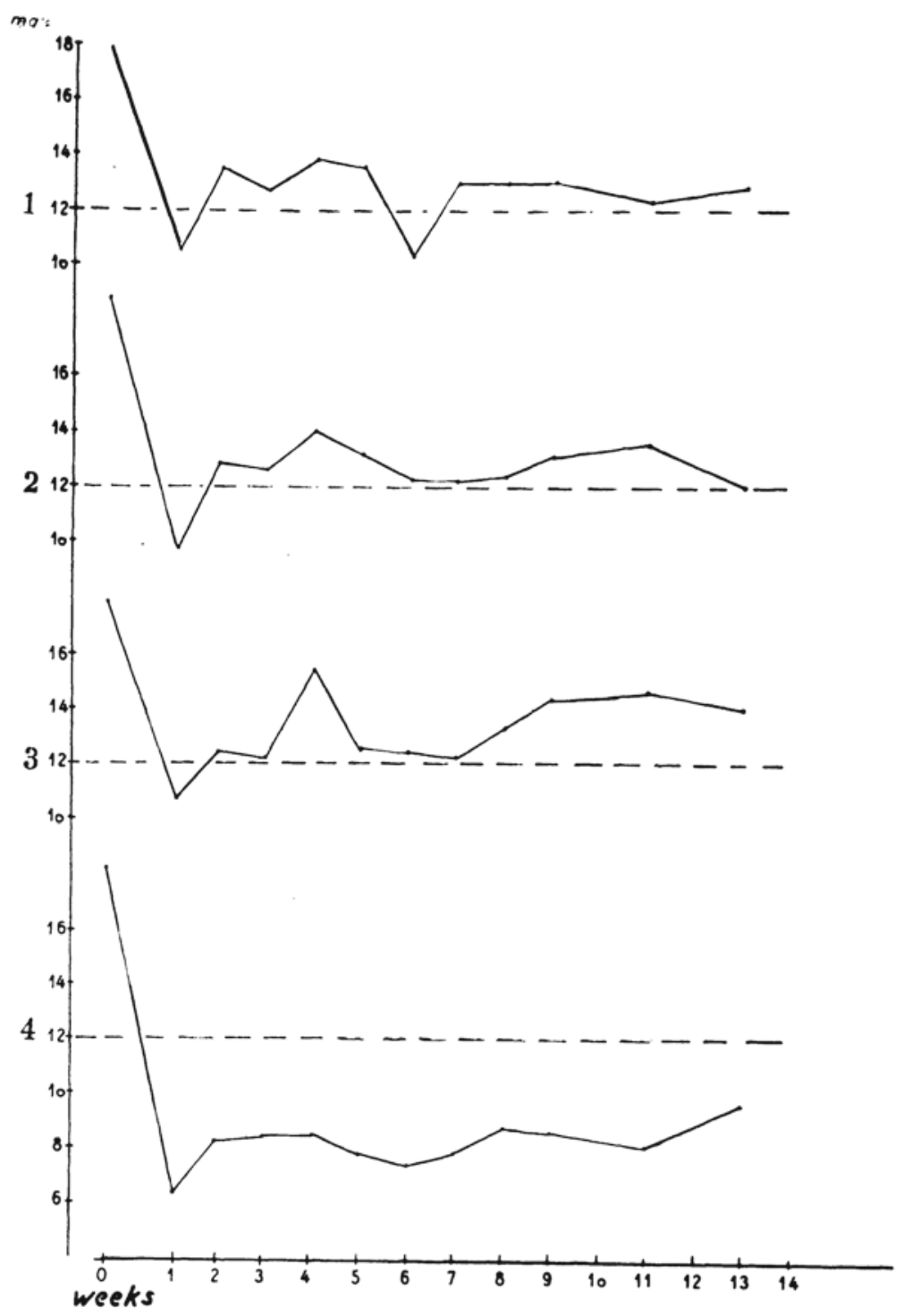

Fig u re 6. Serum inorg. P. Mean values of groups, sv. 514.

Histologically, in groups 2 and 3 the trabeculae in the turbinates were slender, poorly developed with confluence of most tubules. In some areas bone resorption was almost complete with replacement of dense fibrous tissue. Only a few osteoblasts were seen. In group 3 additional marked osteoclastosis was seen. 


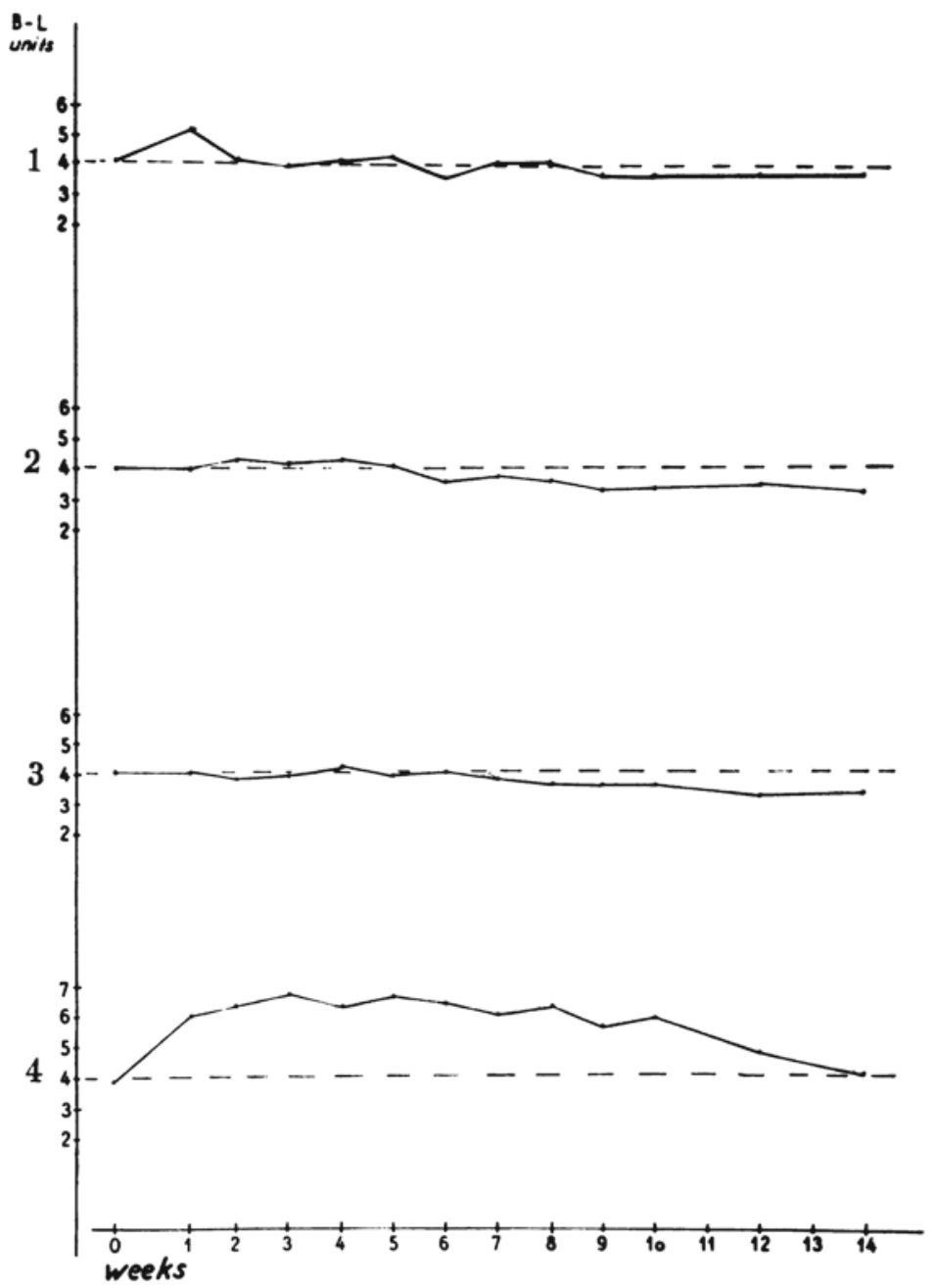

Figure 7. Serum alk. phosphatase. Mean values of groups, sv. 514.

The cortical bone of digits 2 and 5 showed advanced fibrosis. Haversian and Volkmann's canals were wide and filled with firm connective tissue. Several areas showed complete loss of outer circumferential lamellae.

The epiphysial lines were not generally affected. The columns of cartilage cells in the growing zone were regular, and quite normal calcification was found, even in pigs with advanced osteofibrosis (Fig. 12). 


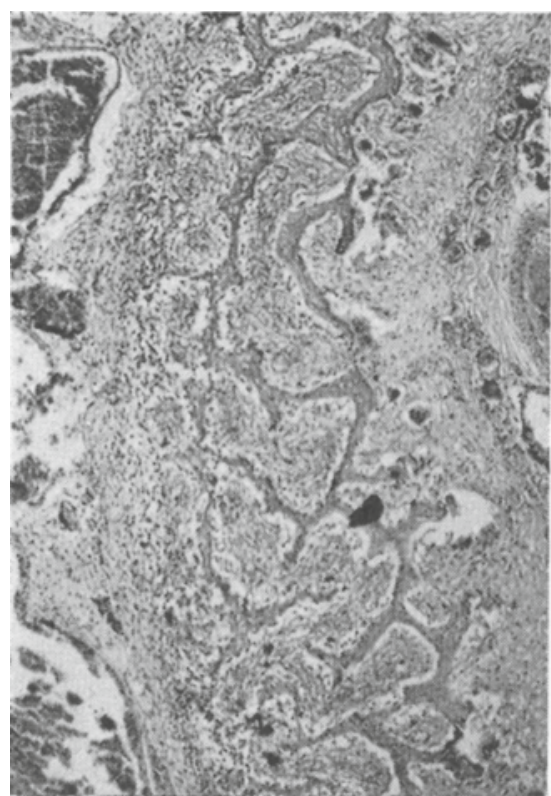

Figure 8. Turbinate from pig no. 664 , group 3 , sv. 514. The trabeculae are slender, uneven, poorly developed with poor coherence. H. E. $\times 50$.

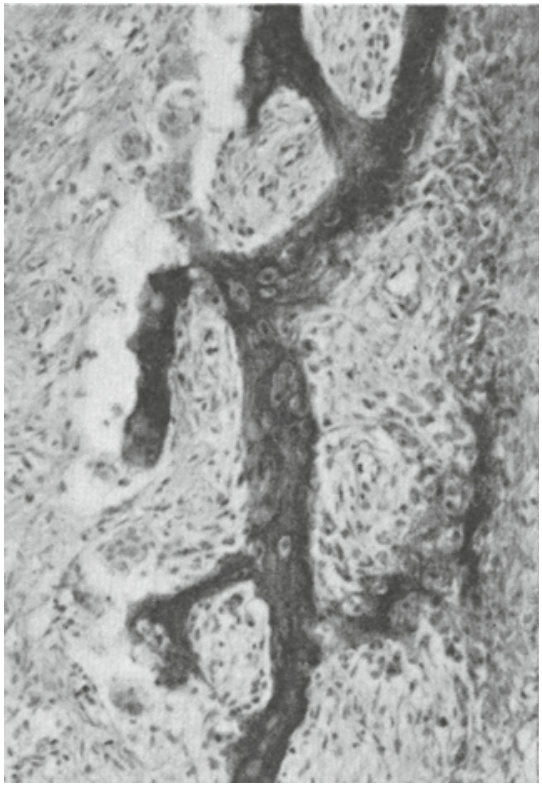

F'i g u r e 9. Turbinate from pig no. 634, group 3, sv. 514. Marked osteoclastosis, poor mineralization and advanced fibrosis with some pericytic osteolysis. van Gieson $\times 160$.

In group 4 the bone tissue was found well mineralized. The trabeculae in the turbinate and the laminar structure in cortical bone were, however, less developed as compared to the bone in experiment sv. 474 group 4, and several osteoclasts were seen.

\section{DISCUSSION}

As shown in Table 1 the diet composed of barley and soybean meal contained $0.09 \% \mathrm{Ca}$ and $0.40 \% \mathrm{P}$. When supplemented with inorg. Ca and $\mathrm{P}$ these levels were increased in various proportions.

Daily gain and feed conversion were not affected by the different $\mathrm{Ca}$ and $\mathrm{P}$ levels in experiment sv. 474 and only slightly depressed in the groups with the most unfavourable $\mathrm{Ca}: \mathrm{P}$ ratio in experiment sv. 514. Combs et al. (1962) and Combs \& Wallace (1962) found in young pigs a decrease in daily weight gain and feed conversion when increasing dietary Ca content from 


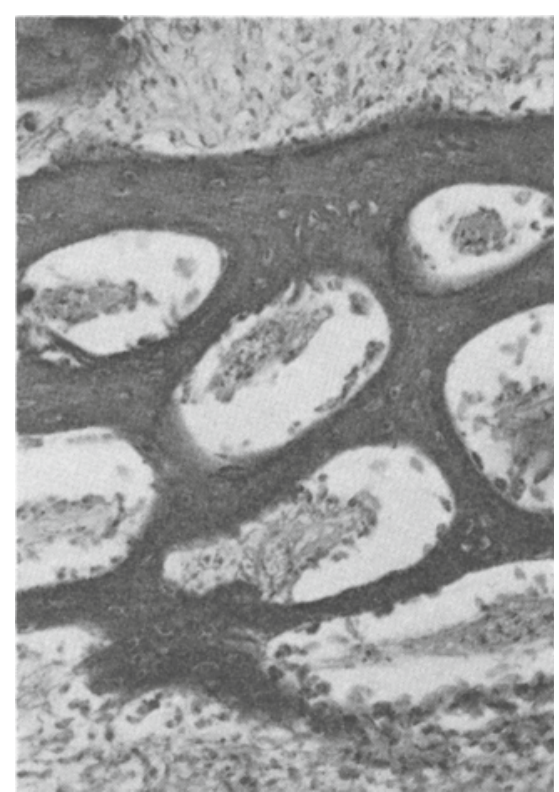

Fi g u r e 10 . Turbinate from pig no. 661, group 4, sv. 514. Trabeculae are fairly well mineralized, but generally bone formation is somewhat depressed with higher degrees of osteoclastosis in comparison with the bone in experiment sv. 474, group 4 . van Gieson $\times 160$.

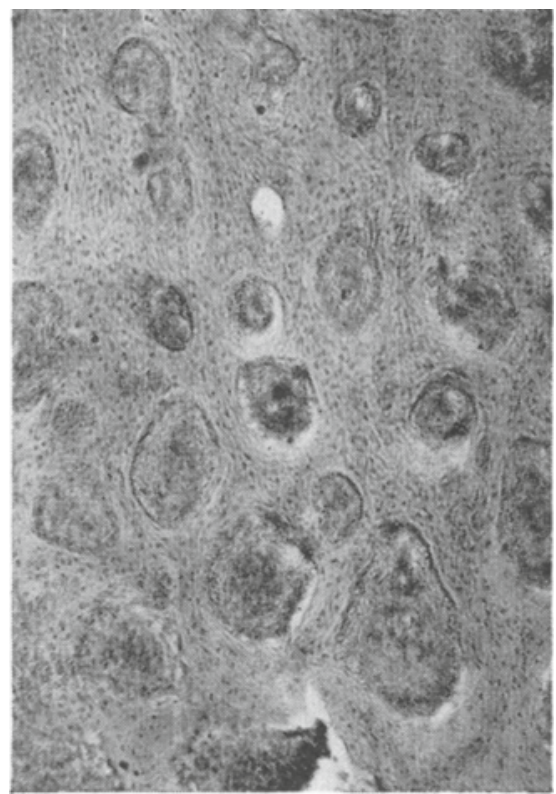

Figure 11. Digitus 2 from pig no. 634 , group 3 , sv. 514. Advanced osteofibrosis. Haversian and Volkmann's canals are filled with connective tissue and the laminated bone substance is poorly mineralized. H. E. $\times 50$.

$0.40 \%$ to $0.88 \%$. Chapman et al. (1962) found that the highest weight gain and the maximal ash content and breaking strength of bone were obtained at $0.7 \% \mathrm{Ca}$ and $0.5 \% \mathrm{P}$ in pigs from 11 to $91 \mathrm{~kg}$. In pigs from 5 to $91 \mathrm{~kg}$ Brown et al. (1966) recorded the best feed conversion at $0.8 \% \mathrm{Ca}$ and $0.6 \% \mathrm{P}$, while a slightly higher daily weight gain was obtained when increasing Ca-P levels to $1.0-0.8$ or $1.2-1.0$. In accordance with our results Libal et al. (1969) recently reported that levels of $\mathrm{Ca}$ and $\mathrm{P}$ in diet for growing pigs may vary considerably without affecting daily gain and feed conversion, although bone formation as shown by breaking strength and bone weight were affected.

Low Ca content in the feed and even low Ca and high $\mathrm{P}$ only induced a slight decrease in serum $\mathrm{Ca}$, quickly followed by an increase and stabilization, presumably due to an increased ac- 


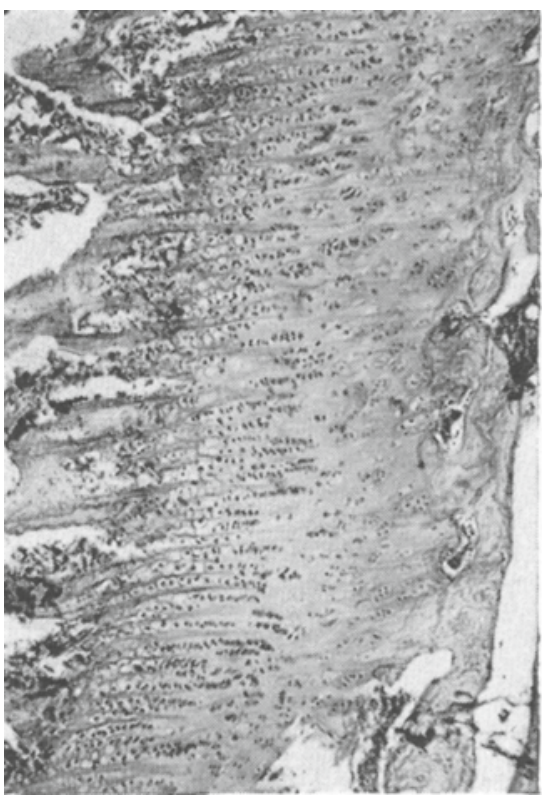

F i g u r e 12 . Epiphyseal line from pig no. 634, group 3, sv. 514. No marked signs of rickets were observed in any group.

H. E. $\times 50$.

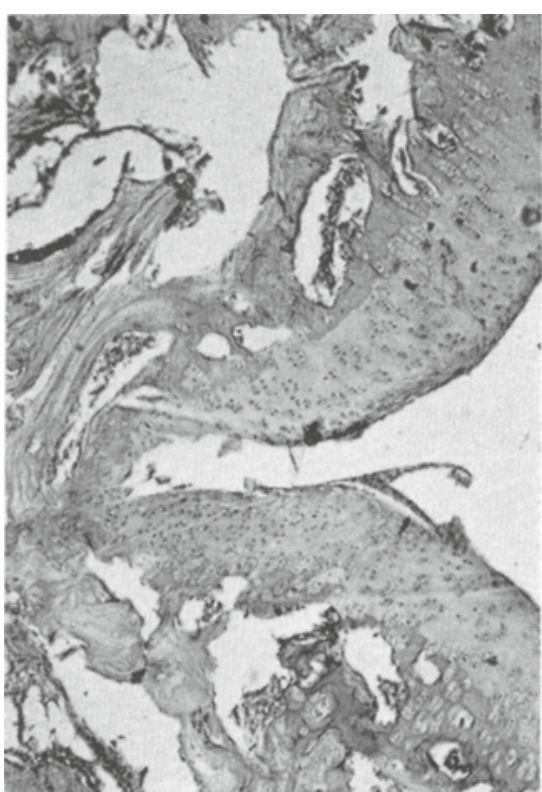

Figure 13 . From pig no. 634, group 3, sv. 514. Invaginations on an unloaded cartilaginous joint surface with collaps of supporting bone structure. H. E. $\times 50$.

tivity in the parathyroid glands. Towards the end of the experiment the level was slightly reduced. Thus, occasional determination of serum $\mathrm{Ca}$ is of very limited value when detecting nutritional Ca deficiency, unless the deficiency has lasted for several months. Only with an additional deficiency of vitamin D a significant hypocalcemia may be expected within the growing - finishing period as recently shown by Baustad et al. (1967).

Unilateral high Ca intakes, however, induced within a week or 10 days a significant rise in serum $\mathrm{Ca}$ in all 10 pigs of the group, and a corresponding decrease in serum $\mathrm{P}$ was seen. The rise in Ca to non-physiological levels must be due to the unfavourable $\mathrm{Ca}: \mathrm{P}$ ratio in the feed $(1.2: 0.4)$. Brown et al. who used the same level of $\mathrm{Ca}$ but a corresponding high $\mathrm{P}$ content (1.2:1.0) did not record any general and lasting hypercalcemia.

The diagnostic importance of the level of alkaline phosphatase in growing animals is not clear. In this experiment no change in serum alkaline phosphatase occurred in groups 2 and 3 in 
spite of severe osteolysis and other disturbances in bone development. When a significant rise in serum alkaline phosphatase has been recorded in pigs - in experimental rickets e. g. - it has been inversely related to serum Ca. In this experiment, however, the induced hypercalcemia was related to increased serum alkaline phosphatase.

In atrophic rhinitis, among others Bendixen (1957, 1962), Björklund (1958), and Baustad et al. consider disturbances in bone formation - at least local - an important feature. Moreover, Brown et al. are of the opinion that inadequate Ca feeding in connection with high growth rate resulting in a generalized osteitis fibrosa is the main etiological factor in atrophic rhinitis. $1.2 \% \mathrm{Ca}$ and $1.0 \% \mathrm{P}$ proved to be effective in preventing atrophic rhinitis. These results could not be confirmed in the experiments presented here. The frequency of atrophic rhinitis was affected neither by the level of Ca nor by the Ca: $\mathrm{P}$ ratio in the feed even though generalized osteodystrophia fibrosa was produced. This could be due to the fact that Brown et al. started their experiments with younger pigs and by feeding ad lib. allowed a somewhat faster growth rate than we did. It is possible that older pigs are less sensitive to changes in the $\mathrm{Ca}: \mathrm{P}$ ratio than younger pigs. On the other hand, since the growth rate was the same for all groups in experiment sv. 474, and only 5-10\% depressed in groups 2-4 in experiment sv. 514, and since spontaneous atrophic rhinitis arose - indicating that some of the litters were predisposed for this disease - one would expect either a higher incidence among the pigs fed the unfavourable Ca diets or a lower incidence among the pigs fed the favourable Ca diet - if Ca deficiency is the main etiological factor in atrophic rhinitis. Furthermore, Baustad et al. produced experimentally osteitis fibrosa without provoking atrophic rhinitis.

Therefore, it is concluded that atrophic rhinitis may occur simultaneously with or independent of a generalized diet-induced osteodystrophy - at least during the growth period $20-90 \mathrm{~kg}$.

As neither clinical nor histopathological symptoms of rickets were found in these 2 experiments, and taking into consideration findings by Brown et al. and Baustad et al., it may be concluded that even very unfavourable Ca: $\mathrm{P}$ ratios in the feed are not likely to cause rickets in growing pigs provided that the vitamin D supply is sufficient. 
The results showed that the incidence of degenerative joint lesions and invagination of anticular cartilage did not increase in the pigs on diets $2-4$ with an unfavourable $\mathrm{Ca}: \mathrm{P}$ ratio. The incidence and severity were closer correlated with litters than with diets, indicating that hereditary factors and/or environmental factors during the prenatal and the suckling period play a predominant role in the pathogenesis. Based on the morphology of the lesions, these factors may act somewhere in the Ca resorption or Ca metabolism, but a low dietary Ca level inducing generalized osteodystrophia fibrosa, probably due to secondary hyperparathyreoidism, did not seem to aggravate the joint lesions. Whether higher dietary Ca and P levels can minimize the frequency and severity of cartilage invagination cannot be evaluated from these experiments. The lower incidence recorded in group 4 of experiment sv. 514 and the fact that in experiment sv. 474 only group 4 revealed adequate bone quality may, however, indicate a possibility of minimizing the joint lesions by increasing $\mathrm{Ca}$ and $\mathrm{P}$ levels in the feed. An experiment is implemented in order to elucidate this question.

\section{CONCLUSIONS}

1. Diets with Ca contents ranging from 0.48 to $1.2 \%$ had when keeping $\mathrm{Ca}: \mathrm{P}$ ratio constant at $1.2-$ no influence on pig performance.

Ca: $\mathrm{P}$ ratios of $0.1,0.2$ and 3.0 reduced daily gain and feed conversion, and more fat and less meat were deposited.

2. Occasional estimation of serum Ca, serum $P$ and alkaline phosphatase is of very limited value when detecting nutritional Ca deficiency, provided that vitamin D is supplied sufficiently.

3. A lasting, pronounced hypercalcemia and a corresponding decrease in serum $P$ was obtained when supplying the pigs with unilateral high Ca diets.

4. Rickets was not found when using unfavourable Ca:P ratios in vitamin $\mathrm{D}$ sufficient diets.

5. Judged from histomorphological criterion diets only with $1.2 \% \mathrm{Ca}$ and $1.0 \% \mathrm{P}$ resulted in adequate bone quality.

6. The frequency of atrophic rhinitis was not influenced by feeding different $\mathrm{Ca}: \mathrm{P}$ ratios and levels during the growing period $20-90 \mathrm{~kg}$. 
7. The incidence of degenerative joint lesions was closer correlated with litters than with diets.

\section{REFERENCES}

Baustad, B., J. Teige jr. \& S. Tollersrud: The effect of various levels of calcium, phosphorus and vitamin $\mathrm{D}$ in the feed for growing pigs with special reference to atrophic rhinitis. Acta vet. scand. $1967,8,369-389$.

Bendixen, H. C.: Veterinære problemer i forbindelse med sygelige tilstande hos unge grise med særligt henblik på dystrofiske tilstande i svinets næsehule. (Veterinary aspects in relation to diseases in young pigs with special reference to dystrophic conditions in the nasal cavity). Medlemsbl. danske Dyrlægeforen. 1957, 40, 93-118.

Bendixen, H. C.: Virkningen af ernæring på moderdyret og milieubetingede indvirkninger på fosteret under drægtigheden. (The influence of the nutrition of the mother animal and environmental condition on the foetus during gestation). Medlemsbl. danske Dyrlægeforen. 1962, 45, 85-103.

Bessey, D. A., O. H. Lowry \& M. J. Brock: A method for the rapid determination of alkaline phosphatase with five cubic millimetres of serum. J. biol. Chem. 1946, 164, 321-329.

Björklund, N. E.: Atrophic rhinitis of pigs. Thesis. Stockholm 1958.

Brown, W. R., L. Krook \& W. G. Pond: Atrophic rhinitis in swine. Etiology, pathogenesis, and prophylaxis. Cornell Vet. Suppl. 1, 1966, 56, $127 \mathrm{pp}$.

Chapman, H. L. jr., J. Kastelic, G. C. Ashton, P. G. Homeyer, C. Y. Roberts, D. V. Catron, V. W. Hays \& V. C. Speer: Calcium and phosphorus requirements of growing-finishing swine. J. Animal Sci. 1962, 21, 112-118.

Combs, G. E., J. M. Vandepopuliere, H. D. Wallace \& M. Koger: Phosphorus requirement of young pigs. J. Animal Sci. 1962, 21, 3-8.

Combs, G. E. \& H. D. Wallace: Growth and digestibility studies with young pigs fed various levels and sources of calcium. J. Animal Sci. 1962, 21, 734-737.

Christensen, N. O.: Impotentia coeundi in boars due to arthrosis deformans. XV Int. vet. Congr., Stockholm 1953, Proc. Part I, 2, $742-745$.

Eikmeier, H. \& H. Mayer: Untersuchungen über die Abgangsursachen von Zuchtsauen aus Herdbuchbetrieben. (Survey of causes for discarding sows in elite breeding herds). Tierärztl. Umsch. $1965,20,282-284$.

Lauprecht, E., W. Schulze \& W. Bollwahn: Untersuchungen über das Vorkommen von Bewegungsstörungen und Erkrankungen der Gliedmassen bei Fleischschweinen. (Investigations on locomotor disturbances and joint lesions in pigs). Z. Tierzucht. Zücht. Biol. 1967, 83, 297-311. 
Libal, G. W., E. R. Peo jr., R. P. Andrews \& P. E. Vipperman jr.: Levels of calcium and phosphorus for growing-finishing swine. J. Animal Sci. 1969, 28, 331-335.

Madsen, A., H. P. Mortensen, B. Laursen, N. C. Nielsen \& S. Andersen: Foder givet efter ædelyst $\mathrm{i}$ foderautomat. (Feeding experiments with bacon-pigs. Ad libitum feeding by selffeeders). Land $\varnothing$ konomisk Fors $\emptyset$ gslab. årbog 1966, 47-51.

Nielsen, $N$. C.: Specielle undersøgelser vedr. knogle- og ledforandringer ved fors $\emptyset$ g med færdige foderblandinger til slagtesvin. (Investigations on bone and joint lesions in fast growing pigs). Landøkonomisk Fors $\varnothing$ gslab. ărbog 1965, 65-66.

Nordrum, E.: Rakittlignende tilstander hos slaktegris. (Rickets-like conditions in bacon-pigs). Medlemsbl. norske Vet.-Foren. 1968, $20,389-392$.

Perkin-Elmer: Analytical methods for atomic absorption spectrophotometry, 1964.

Sabec, D., E. Schilling \& L. Cl. Schultz: Eine Arthrosis deformans des Sprunggelenkes beim Schwein. (Arthrosis deformans of the hock joint in pigs). Dtsch. tierärztl. Wschr. 1961, 68, 231-236.

Schilling, E.: Veränderung der Sprunggelenke bei einem lahmenden Schwein. (Alterations in the hock joint of a lame pig). Züchtungsk. 1958, 30, Sonderheft 5, Verlag Ulmer, Stuttgart.

Shinowara, G. Y., L. M. Jones \& H. L. Reinhart: The estimation of serum inorganic phosphate and "acid" and "alkaline" phosphatase activity. J. biol. Chem. 1942, 142, 921-933.

Thurley, D. C.: Arthropathy in pigs. Proc. roy. Soc. Med. 1965, 58, $369-370$.

\section{SUMMARY}

Two experiments comprising a total of 80 Danish Landrace pigs in the period $20-90 \mathrm{~kg}$ live-weight were carried out to study the effect of dietary levels and ratios of $\mathrm{Ca}$ and $\mathrm{P}$ on serum values of $\mathrm{Ca}$, inorg. $\mathrm{P}$, and alkaline phosphatase and on the development of degenerative arthritis and atrophic rhinitis.

In both experiments each $\mathrm{kg}$ feed (Table 1) was supplemented with 600 i. u. vitamin $\mathrm{D}_{3}$ and 80 p. p. m. Zn.

In the first experiment the Ca: $\mathrm{P}$ ratio was 1.2 and the amount of Ca increased from $0.48 \%$ to $1.20 \%$ without influencing daily gain, feed conversion, carcass performance (Table 2) or frequency of atrophic rhinitis (Table 3 ). The Ca: $\mathrm{P}$ ratio in scapula was 2.15 . Only when the diet was supplemented with $1.20 \% \mathrm{Ca}$ and $1.00 \% \mathrm{P}$ the bone quality was histomorphologically adequate (Figs. 1-4).

In the second experiment various $\mathrm{Ca}: \mathrm{P}$ ratios (ranging from 0.1 to 3.0 ) were compared with the recommended level and ratio of $0.72 \% \mathrm{Ca}$ and $0.60 \% \mathrm{P}$. Performance of pigs on the normal level was better than for the other pigs ('Table 4). Clinically, various degrees of leg-weakness and -deformation occurred, most pronounced in the high $\mathrm{Ca}$ - low $\mathrm{P}$ group. Very little lameness and no convulsions were observed. Marked hypocalcemia was not found. Unilateral high Ca intake 
increased serum Ca significantly, and serum alkaline phosphatase slightly, and decreased serum $\mathrm{P}$ (Figs. 5-7). Advanced pericytic osteolysis, poor mineralization and generalized osteodystrophia fibrosa were found in the low Ca groups (Figs. 8-13). The groups showed no differences in frequency of atrophic rhinitis (Table 5), and rickets was not observed.

The incidence of degenerative joint lesions was not increased in pigs on the unfavourable $\mathrm{Ca}: \mathrm{P}$ ratios, and depended apparently more on litters than on diets.

\section{SAMMENDRAG}

Forskellige mængder kalcium og fosfor $i$ foderet til slagterisvin. Indflydelse på serumkoncentrationer og knogleudvikling.

To fors $\varnothing \mathrm{g}$, hver omfattende $\mathbf{4 0}$ grise fra 10 kuld i vækstperioden $20-90 \mathrm{~kg}$ legemsvægt, er gennemført med henblik på at unders $\emptyset$ ge indvirkningen af forskellige mængder og forhold af $\mathrm{Ca}$ og $\mathrm{P}$ i foderet, dels på serumværdier af Ca, uorganisk $\mathrm{P}$ og alkalisk fosfatase, dels på udvikling og forekomst af degenerative ledlidelser og atrofisk rhinitis.

I begge eksperimenter er fors $\varnothing$ gsfoderet (tabel 1) tilsat 600 i. e. vitamin $\mathrm{D}_{3}$ pr. $\mathrm{kg}$ og 80 p. p. m. Zn.

I det f $\varnothing$ rste fors $\varnothing \mathrm{g}$ holdtes Ca:P forholdet konstant 1,2. Mængden af calcium varieredes fra $0,48 \%$ til $1,20 \%$ af t $\varnothing$ rfoder. De 4 fors $\varnothing$ gshold viste ingen forskel i daglig tilvækst, foderforbrug, slagtekvalitet (tabel 2) eller frekvens af atrofisk rhinitis (tabel 3). Ca:P forholdet $i$ knogleaske (scapula) var ens for alle hold - 2,15. Varierende grader af knogleresorption blev påvist mest udtalt i hold 1, men også $\mathbf{i}$ hold 2 og 3 . Kun i hold 4 (1,2\% Ca i foderet) fandtes knogleudviklingen histomorfologisk adækvat (fig. 1-4).

I det andet fors $\emptyset \mathrm{g}$ blev forskellige $\mathrm{Ca}: \mathrm{P}$ forhold (varierende fra 0,1 til 3,0) sammenlignet med de anbefalede normer 0,72\% $\mathrm{Ca}$ og $0,60 \% \mathrm{P}$ (hold 1). Foderudnyttelse og slagtekvalitet fandtes noget bedre for hold 1 end for de $\emptyset$ vrige hold. Klinisk påvistes varierende grader af bevægelsesforstyrrelser og abnorm benstilling mest udtalt i hold 4 (høj Ca - lav P). Der iagttoges kun fả og kortvarige tilfælde af $\phi$ mbenethed og ingen krampeanfald. Ved ugentlige serum-Ca bestemmelser påvistes et kortvarigt fald efter 3 uger $\mathrm{i}$ hold 2 og 3 og et andet moderat fald efter ca. 11 uger. Udtalt hypocalcæmi blev ikke påvist. Ensidigt højt Ca-indhold i foderet (hold 4) resulterede i en varig markant for $\varnothing$ gelse af serum-Ca (14-16 mg\%), en let stigning $\mathrm{i}$ alkalisk fosfatase og et relativt fald i serum-P (fig. 5-7). Scapulas vægt og askeindhold var signifikant højere $\mathrm{i}$ hold 1 og 4 end i hold 2 og 3 (tabel 4). Udtalt resorption af benvæv, dårlig mineralisering og generaliseret osteodystrophia fibrosa påvistes hos hold 2 og 3 . Rachitis blev ikke påvist (fig. 8-13). Holdene viste ingen forskel i frekvens af atrofisk rhinitis (tabel 5). Forekomst og sværhed af degenerative ledlidelser $\emptyset$ gedes ikke ved de ugunstige Ca: $\mathrm{P}$ forhold og fandtes at variere mere mellem kuld end mellem hold. 